\title{
日本建築学会賞（作品）岩見沢複合駅舎の利用実態と空間特性 ACTUAL CONDITIONS AND SPATIAL CHARACTERISTICS OF IWAMIZAWA COMPOUND STATION BUILDING WITH THE PRIZE OF AIJ 2010
}

\author{
長谷部久人*，森傑** \\ Hisato HASEBE and Suguru MORI
}

\begin{abstract}
Design competitions are introduced into many building types for selecting ideas and plans to realize good quality of these facilities. However, it is seldom evaluated strictly on actual conditions after the competition or the prize. This paper aims to review the competition process for Iwamizawa compound station building with the prize of AIJ 2010, and analyze spatial characteristics based on the actual conditions of using the complex building. Many activities are observed same as expected cases in the competition. On the other hand, the main hall where is important space in the design concept makes some conflicts on persons' usage because of occupations by particular types of utilization.
\end{abstract}

Keywords: design competition, station, spatial characteristic, actual condition, post occupancy evaluation, the prize of AIJ 設計コンペ, 駅舎, 空間特性, 利用実態, 入居後評価, 日本建築学会賞

\section{1. 目的と背景}

本研究は、JR としては初めて一般公募型コンペが実施された岩 見沢複合駅舎を取り上げ、設計コンペで評価された建築構成と竣工 後の利用実態からその空間特性を分析することで、採用された設計 手法の効果と課題を明らかにすることを目的とする。岩見沢複合駅 舎は、2010 年日本建築学会賞（作品）や 2009 年度グッドデザイン 大賞などを受賞し、意匠面のみならず、市民参加などの計画・設計 プロセスにおいても高く評価されている。

近年、設計者の創意工夫を引き出すことで、より質の高い生活環 境を実現することを目指して、様々な種類の施設において設計コン ペが導入されている。しかしながら、これら設計コンペにより実現 された建物は、竣工時には大きく注目されたり各種建築賞を受賞し たりするものの、第 3 者により実際の利用状況や不具合などについ て追跡的に調查され、設計コンペや受賞における評価と比較分析さ れることはほとんどない。設計コンペという手法の本来の目的から みれば、審査によって評価された提案が実際に有意義であったか否 かを検証することは重要である。

一方、駅舎の性質に関する既往研究としては、例えば、竹澤らに よるレパートリー・グリッド発展手法を活用したアンケート調査に よる「駅らしさ」を感じる認識構造の研究がある ${ }^{1)}$ 。予備調査アン
ケートから「駅らしさ」を構成する要素を物理的要因と心理的要因 に分類し、アンケート調査から得られた回答よりそれぞれの分類項 目と「駅の規模」「JR利用頻度」「年齢層」の属性種別毎および「駅 らしく感じる具体的な場所」との関係を分析しており、市民の認知 構造から今後の駅舎および駅舎と周辺地域との関わり方を考察して いる点で興味深い。また、駅舎の利用実態に関するものとしては、 諏訪らによる建築家によって設計された駅舎を対象とした駅構内を 中心とする行動観察についての報告がある ${ }^{2)}$ 。駅舎が交通連結点と しての役割だけでなく文化の発信源およびユミュニケーションの場 として機能している効果や電車到着時にコンコース中央付近が混雑 するなどの問題点を明らかにしており、特徴的な設計による駅舎を 対象として利用実態からの評価を試みた点で意義深い。

これら既往研究を踏まえ、本研究は、日本建築学会賞（作品）を 受賞した岩見沢複合駅舎について、設計コンペの全応募提案の傾向 を把握し、最優秀案の複合駅舎としての建築構成の特徴を位置づけ る。そして、コンペ要領において駅舎と岩見沢市施設の一体化の方 法として示唆されたセンターホール $(\mathrm{CH})$ に注目し、実施設計にお ける $\mathrm{CH}$ の設計意図と竣工後の利用実態を比較検証することで、駅 舎と他施設との複合化・共有化の設計手法の一つである $\mathrm{CH}$ の有効 性と課題を明らかにすることを目指す。

\footnotetext{
* UID 一級建築士事務所 修士 (工学)

** 北海道大学大学院工学研究院 教授 ·博士 (工学) 


\section{2. 岩見沢複合駅舎デザインコンペの概要}

2004 年 3 月にJR として初めてとなる一般公募型設計コンペ「岩 見沢駅舎建築デザインコンペ」が開催され、応募提案の中から一次 審査の匿名投票および二次審査の公開審查を経て最優秀賞が選出さ れた（表 1)。設計コンペ終了後の審査員による「北側のファサー ドはホーム側に対して閉鎖的ではないか」という意見を受け、設計 コンペ最優秀案の一部が見直しがなされ、JR 北海道がホームの一 部を新たに敷地として提供することで、実施設計において設計の変 更が行われた。具体的には、最優秀案での駅前広場側にガラスの開 口と動線空間が配置された構成から、実施設計では北側にも同様に 開口を確保し、機能諸室を内包したヴォリュームをガラスの開口と 動線空間が包み込む構成へ変化することとなった（図 1）。

\section{3. 岩見沢複合駅舎の計画内容の分析}

\section{3-1. 分析方法}

岩見沢複合駅舎について、設計コンペとその後の実施設計を通じ て意図され評価された計画内容を把握するため、岩見沢市・JR 北 海道・設計者から得られた各種資料の分析を行った ${ }^{3 \sim 7)}$ 。また、資 料情報の裏付けを得るために、設計者と協力が得られた審査員 2 名 へのヒアリングを実施した。そこで得られたコメントおよび発言の 中から、岩見沢複合駅舎の建築構成に言及しているものを抽出し、

表 1 岩見沢駅舎建築デザインコンペの概要

\begin{tabular}{|c|c|}
\hline 名称 & 岩見沢駅舎建築デザインコンペ \\
\hline 提案対象 & 岩見沢駅舎（駅施設・市施設）、南北自由通路 - 昇降棟、周辺施設 \\
\hline 提案内容 & $\begin{array}{l}\text { 1. 岩見沢のまちの顔となる駅、変わらない価值をもつ駅舎の提案 } \\
\text { 2. 地域文化を担い、地域交流の拠点となる駅舎の提案 } \\
\text { 3. 建設費や維持管理費の低減のための提案 } \\
\text { 4. 駅舎と周辺施設、特に駅前広場との調和を考慮した提案 } \\
\text { 5. 中心市街地と駅との積極的な関係の提案 }\end{array}$ \\
\hline \multirow{3}{*}{$\begin{array}{l}\text { 審査方法 } \\
\text { (2 段階) }\end{array}$} & 一次審査 2005 年 2月 11 日 \\
\hline & $\cdots$ 公開ヒアリング \\
\hline & 2005 年 2 月 6 日〜 8日 \\
\hline $\begin{array}{l}\text { 審査 } \\
\text { 委員会 }\end{array}$ & 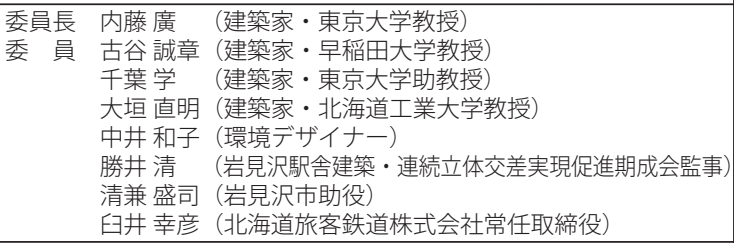 \\
\hline 主催 & (主催) 北海道旅客鉄道株式会社 (後援) 岩見沢市 \\
\hline
\end{tabular}

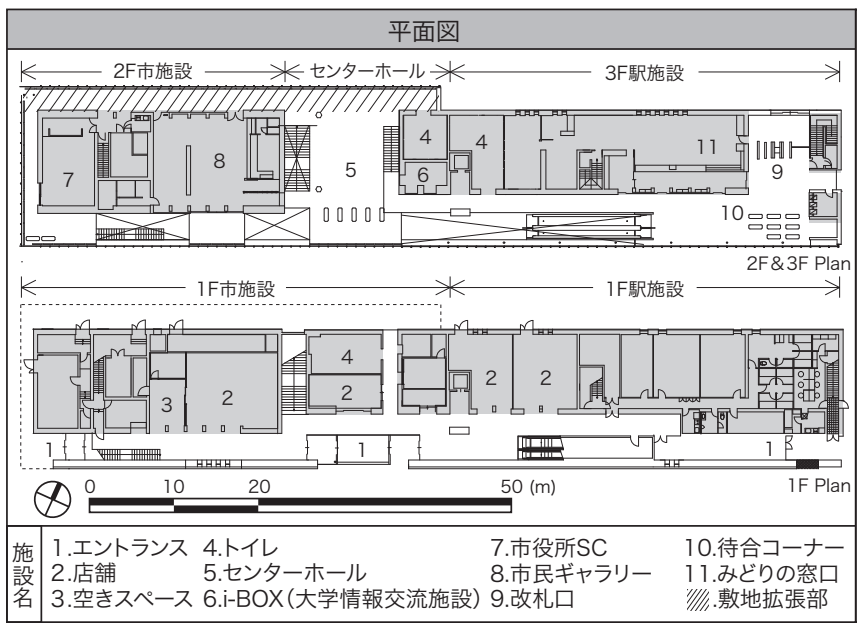

KJ 法を参照した方法で計画内容を 6 つに分類した（表 2)。

\section{3-2. 計画内容と建築構成の要点（表 2)}

[日常] の計画内容では、諸室のヴォリュームとガラス開口の間 にあるセンターホール（以下、CH）や待合コーナーにおいて、利用 者の日常的な滞留や市民活動が営まれることが期待されている。ま た、[賑わい］の計画内容では、駅舎特有の電車の往来による人の 動きを賑わいとして活かし、吹き抜け空間やガラスの開口を通して 街へ開くことが意図されている。このように、日常性・拠点性といっ た広く公共施設として求められる性質が言及され評価されている。

[利便］の計画内容では、南側に一直線に配置された利用者動線 と駅舎の端から端まで見通せる吹き抜け空間によって、サインに頼

表 2 岩見沢複合駅舎の計画内容

\begin{tabular}{|c|c|}
\hline カテゴリー & 具体的な計画内容 \\
\hline [日常] & 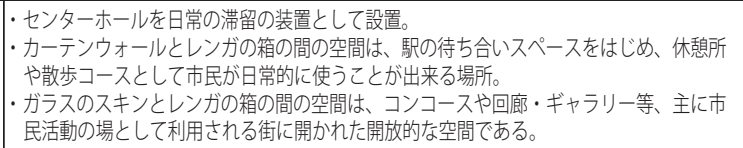 \\
\hline [賑わい] & 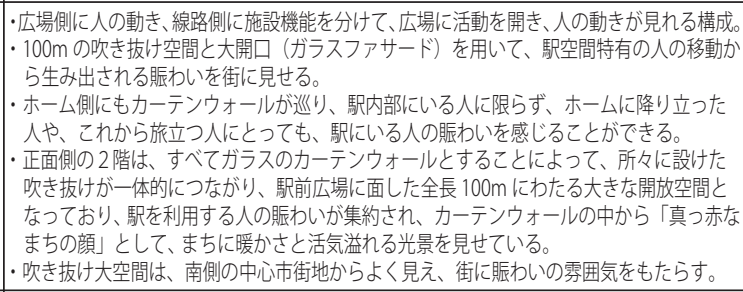 \\
\hline [利便］ & $\begin{array}{l}\text { ·利用者の主動線を駅前広場に面した南側に一直線に配置し、さらに吹き报けを介して1・ } \\
\text { 2階が見通せることで、機能性と分かりやすさに配慮。 } \\
\text { ·見通しの良い空間構成となることで、サイン頼る必要のない、案内性のよいわかりや } \\
\text { すい空間が塞現。 }\end{array}$ \\
\hline [回遊] & 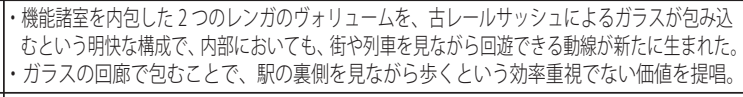 \\
\hline [内外] & 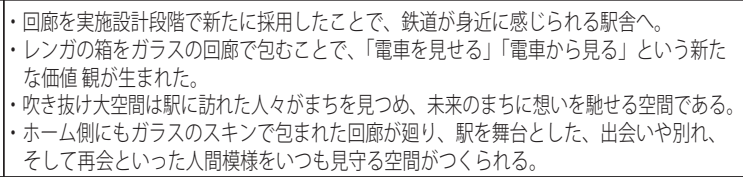 \\
\hline [連続 $]$ & 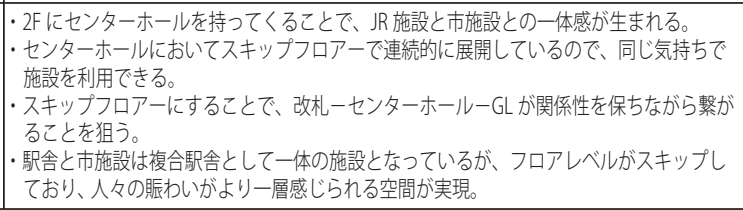 \\
\hline
\end{tabular}
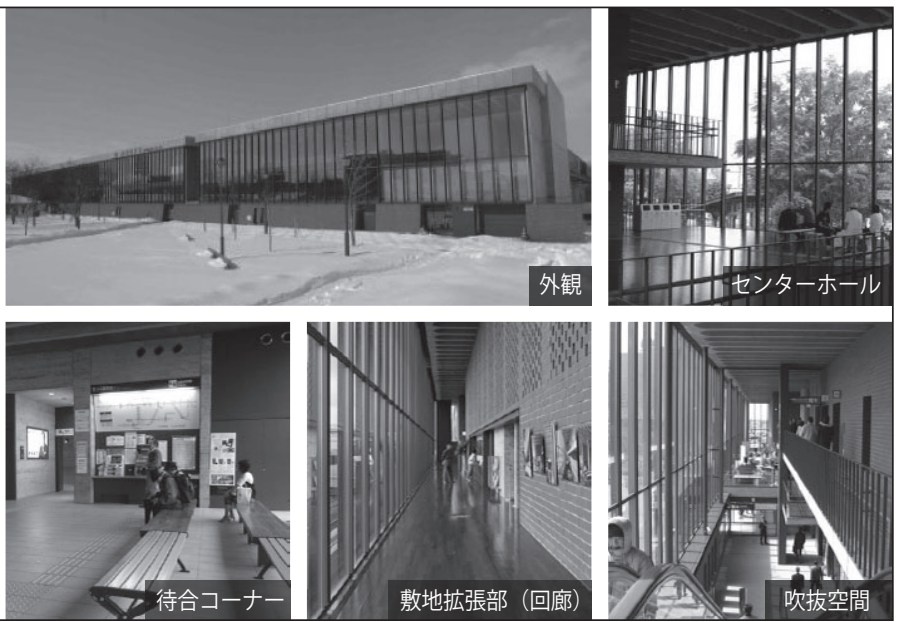

図 1 岩見沢複合駅舎の平面図と主なエリア 
らなくても迷わずに移動できることが目指されている。つまり、駅 舎の基本的な機能として、ウェイファインディングの明快さが重視 されている。

[ 回遊］と［内外］の計画内容では、実施設計にて新たに設けら れた回廊を対象に、街や鉄道を眺めながら歩くというシーンの創出 が意図されている。駅舎ならではの空間演出が試みられている。

[ 連続 ] の計画内容では、2 階に $\mathrm{CH}$ を配置することで JR 関連施 設と市関連施設、地上階と 3 階（改札口）の活動や賑わいが連続的 に繋がることが意図されている。複合駅舎としての一体性が重視さ れている。

これら計画内容の分析から、岩見沢複合駅舎の建築構成の要点と して、(1)駅施設と市施設・地上階と改札階を繋ぐよう 2 階に配置さ れた CH、(2)機能諸室のヴォリュームをガラスの回廊が包む回遊性 のある空間、(3)南側に配置された吹き抜けた一直線な動線空間、が 導き出される。

\section{4. 全応募提案の建築構成の分析}

\section{4-1. 分析方法}

関連資料 ${ }^{3)}$ に収録されている設計コンペ応募提案 353 作品のうち、 室名などの記載がない 19 作品を除く 334 作品を対象とした。

デザインコンペの開催要領に記載されてある「提案説明書、提案 図面作成にあたっての主な条件」において、設計条件として、既存 の JR 跨線橋と連結させるために改札口は 2 階（既存 JR 跨線橋の高 さ）へ設置することと、JR 北海道管理の駅施設と岩見沢市管理の 市施設を複合するために約 $16 \mathrm{~m} \times 100 \mathrm{~m}$ のリニアな敷地形状を活 用寸ることが求められている。よって、前者から導かれる(a地上階 〜改札階（2 階）への連続性の確保と、後者から導かれる(口駅舎／ 市施設の一体性の確保が、当該コンペにおける建築構成上の主たる 課題といえる。

これら@連続性と(b)一体性の視点から、全応募提案を俯瞰的に分 析するための建築要素として、駅施設・市施設利用者の主な目的地 点となる改札口、市役所サービスセンター（以下、SC)、使用方法 は記載されていないが一体化一寄与すると期待され提示された $\mathrm{CH}$ に着目した。

\section{4-2. 改札ロ・サービスセンター・センターホールの配置関係（図 2)}

改札口・SC・CH の各施設が配置されている階層の関係について 全応募提案を分類した結果、設置階の関係としては、各施設がそれ ぞれ異なった階に設置された分散（50）、改札口とCH が同一階（5）、 改札口と市役所 SC が同一階（246）、市役所 SC とCH が同一階（18）、 3 施設が同一階（15）となった（図 2)。主な傾向としては、改札 口と市役所 SC を同一階に設置し、CHを他の階に配置した提案が 73. 7\%を占め、次いで各施設をそれぞれ異なった階に設置した提案 が $15.0 \%$ である。一方、CH と同一階に他の施設が設置されている 建築構成は比較的少なく、全体の傾向としては、CH と他の施設と の平面的な繋がりが重視されていないことが理解できる。

\section{4-3. センターホールを中心とした建築構成の傾向}

各施設の中で、CH は具体的な機能が定められてない一方で、そ れが繋がる階層および施設機能へ大きな影響を与える建築要素であ る。よって、CH 階を経由した他 2 施設（改札口と SC) へのアクセス、 $\mathrm{CH}$ が設置された階層、CH階における動線空間の形状についての分
類を行った。

CH 階を介した他 2 施設（改札口と SC）へのアクセスについて分 類した結果、CHを介して両施設にアクセス（308）、CHを介して市 役所 SC のみにアクセス（11）、CH を介して改札のみにアクセス (0)、 CH を介さずに両施設にアクセス（15）へ分類された（図 3)。全体 の傾向としては、CH を介して両施設にアクセス寸る場合が $92.2 \%$ を占めており、CH が駅施設・市施設利用時の基点となっている。 一方、 $\mathrm{CH}$ を介さずに各施設にアクセス寸る提案は比較的少ない。 特に CH を介して改札口のみアクセス寸る提案は 1 つもみられない ことから、CH が市の管理の下で運用される仕組みが設計手法へも 反映されていることがわかる。

利用者のアクセスに大きく関係する $\mathrm{CH}$ の設置階について分類し た結果、CH 設置階として、B1F（5）、1F（302）、2F（25）、3F（2）となっ た（図 4)。CH が駅施設・市施設利用者との接点となる地上階 (1F) に設置されている場合が $90.4 \%$ を占める。改札口への動線と分離 される可能性の高い $\mathrm{B} 1$ および $3 \mathrm{~F}$ にある場合は非常に少ない。よっ て、提案全般において、CH は利用者がアクセスしやすい $1 \mathrm{~F}$ に設置 することが有効と判断されたことがわかる。

CH 階における動線空間の形状について分類した結果、動線の型 として、ヴォリュームが片側に配置されている片廊下型（107）、ヴォ リュームが両側に配置されている中廊下型（146）、ヴォリュームが 独立している回廊型（81）が得られた（図 5)。長手方向への主動 線が現れやすい片廊下型や中廊下型が多くを占め、駅舎内で回遊性 のある構成の回廊型は $24.2 \%$ となっている。奥行きのない敷地形 状が動線計画に影響を与えたことが理解できる。

\section{4-4. 連続性・一体性からみる建築構成の類型}

各施設の配置関係と $\mathrm{CH}$ 階を介した他 2 施設（改札口と SC）への アクセスから@連続性について類型したものが図 6、各施設の配置 関係と CH 階における動線空間の形状からゆ一体性について類型し

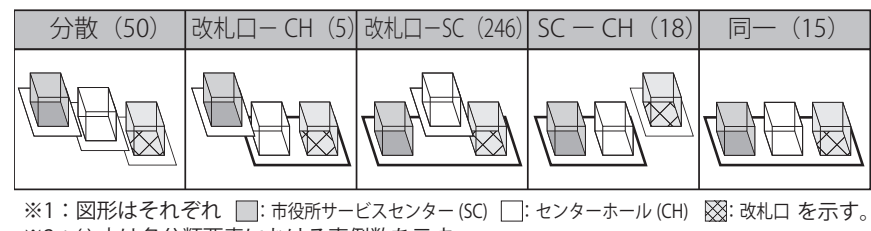
※2: () 内は各分類要素における事例数を示す。

図 2 改札口・サービスセンター・センターホールの配置

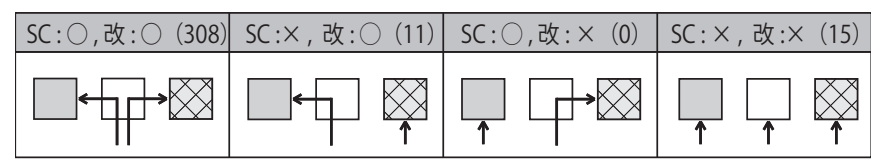

図 3 センターホール階を介した改札ロ・サービスセンターへのアクセス

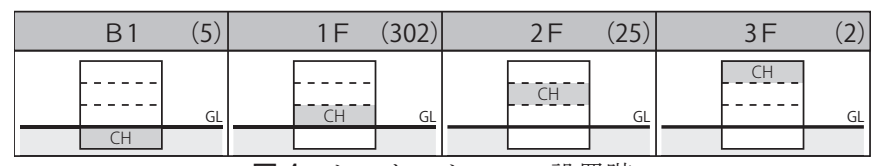

図 4 センターホールの設置階

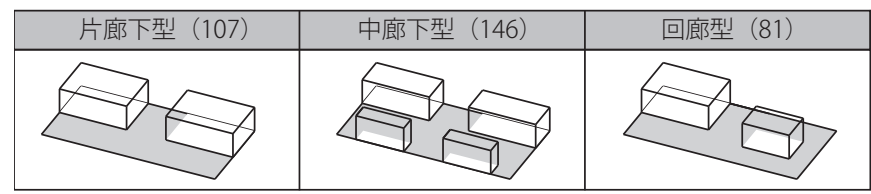

図 5 センターホール階における動線空間の形状 


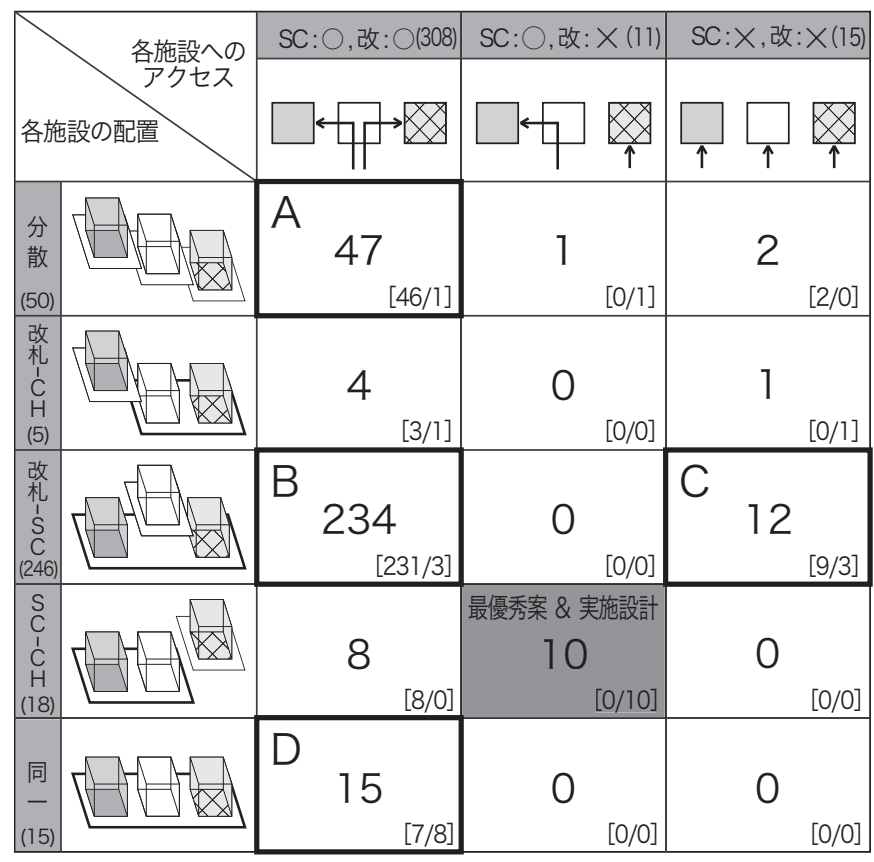

※1 : 表中の数字は各カテゴライズによる事例数を示し、[] 内はセンターホールが配置さ 図 6 施設配置と施設相互のアクセスによる類型

たものが図 7 である。以下、それぞれについて、事例数が多くみら れる類型と最優秀案と実施設計が該当する類型を比較しながら、岩 見沢複合駅舎の建築構成の特徴を分析する。

\section{（a）地上階からの各施設への連続性（図 6)}

事例数が多い類型をみると、各施設が分散し CH 階を介して両施 設にアクセス寸る類型 A は、改札口と市役所 SC が 2 階に配置され ているが、地上階にある $\mathrm{CH}$ の吹き抜けによって水平移動が分断さ ている事例が過半を占める。改札口と市役所 SC が同一階で CH 階を 介して両施設にアクセス寸る類型 B は、地上階にある $\mathrm{CH}$ を中心に 2 階の左右へ市役所 SC と改札口を配置する傾向がある。改札口と 市役所 SC が同一階でCH を介さずに両施設にアクセスする類型C は、

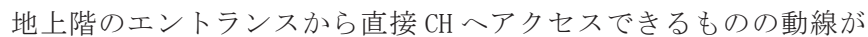
分散する構成となっている。全施設が同一階で CH を介して両施設 にアクセス寸る類型 D は、スロープを用いるなどにより、地上階か ら上階の市役所 $\mathrm{SC} ・ \mathrm{CH} ・$ 改札口へ連続的な繋がりをもたせようと する傾向が見られる。

類型 $\mathrm{A}$ と類型 $\mathrm{B}$ より、CH を地上階に設置し改札口と市役所 $\mathrm{SC}$ を 2 階の左右に配置する構成は全体の $82.9 \%$ を占めており、全応募提 案の俯瞰的な傾向として掴むことができる。

最優秀案と実施設計の類型をみると、市役所 SC と CH が同一階で CH 階を介して市役所 SC のみにアクセス寸る構成となっている。こ の類型の特徵は、全ての該当事例が地上階以外で $\mathrm{CH}$ を配置してい る点である。俯瞰的な傾向と比較すると、市役所 SC と CH が 2 階に あることからそれらの平面的な繋がりは明快である一方で、改札口 は 3 階にあることから CH との距離感が生まれており、CH 階を介し た他 2 施設（改札口と SC）の関係が非対称な構成となっている。

設計コンペ時は、2 階に配置された $\mathrm{CH}$ が地上階と改札階（3 階） を慗ぐスキップフロアの構成である点が評価された。しかし実際に は、地上階から改札階まで直接アクセスできる動線となっており、 2 階に配置されてある市役所 SC と CH が、むしろ改札口利用者から

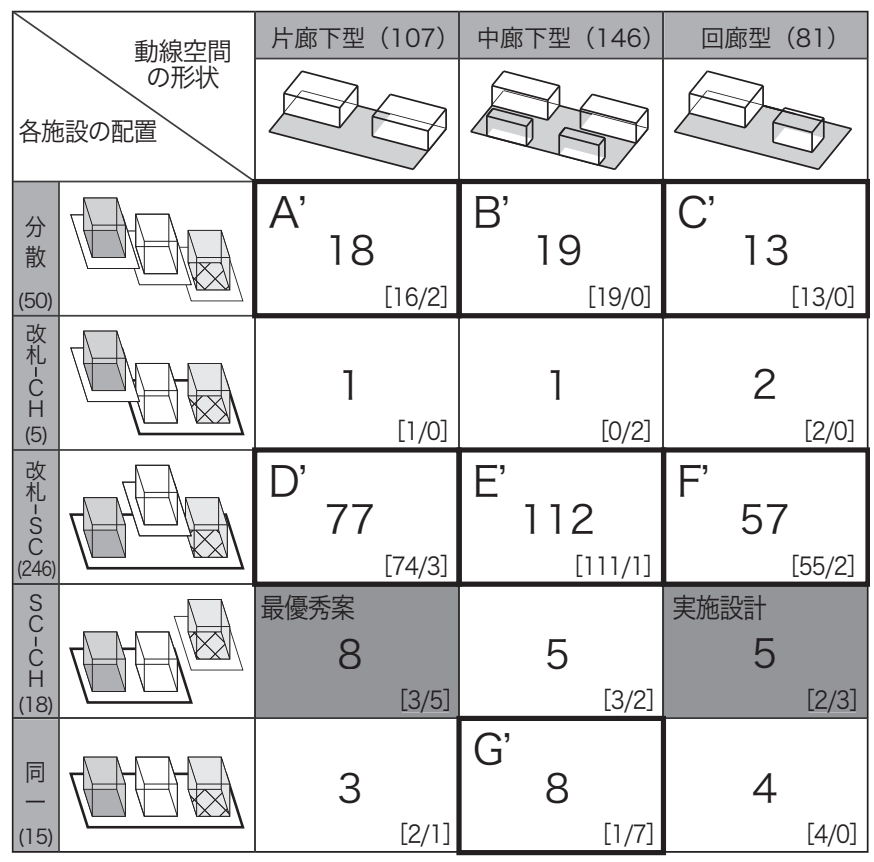

図 7 施設配置と動線空間の形状による類型

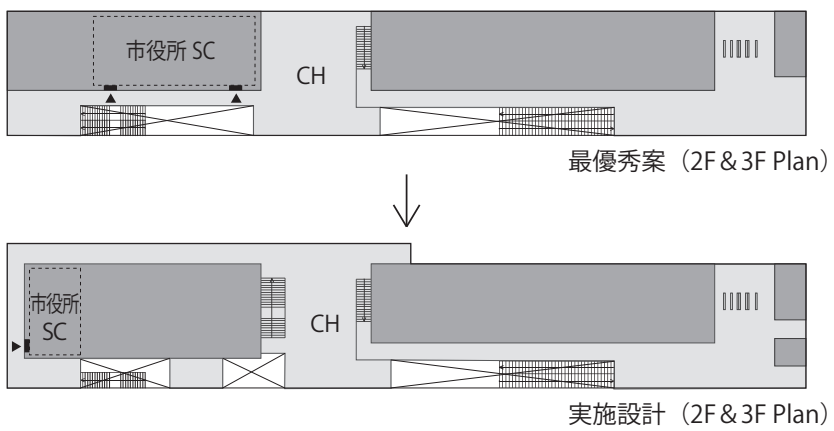

図 8 最優秀案から実施設計への変更箇所 $(2 \mathrm{~F}, 3 \mathrm{~F})$

明確に切り離された建築構成であるといえる。

（b）施設相互の一体性（図 7)

事例数が多い類型をみると、各施設が分散している片廊下型の 類型 $\mathrm{A}^{\prime}$ 、中廊下型の類型 B'、回廊型の類型 C’、および改札と市役 所 SC が同一階である片廊下型の類型 D’、中廊下型の類型 E’、回廊 型の類型 F’（57）は全て CH 階が同一階にないことから、全応募提 案の俯瞰的な傾向としては、一体性の獲得において $\mathrm{CH}$ を平面的に 活用しなかったことがわかる。ただし、その中の多くの事例が、 $\mathrm{CH}$ を吹き抜けとして地上階に配置することで、2 階の市役所 SC と改 札口との繋がりを間接的に確保しようとする提案であった。

それに対して、全施設が同一階で中廊下型の類型 G' は、約 100 $\mathrm{m}$ を貫く中廊下型の動線空間があることから、施設間の一体性が水 平方向に強い建築構成といえよう。

最優秀案と実施設計の類型をみると、最優秀案は市役所 SC と CH が同一階の片廊下型であったが、実施設計ではで回廊型へと变化し ている。設計コンペ時は、市役所 SC と CH の関係は一直線の動線空 間で明快に結ばれていた点が評価された。しかし、実施設計では北 側に新たに動線空間が付加されたことで、南側は視線が通りつつ も北側は動線としては選択性の高い空間となった（図 8)。さらに、 設計変更により市役所 SC が CH から最も離れた位置関係になったこ 
表 3 利用実態調查の概要

\begin{tabular}{|c|c|c|c|c|c|}
\hline & \multicolumn{2}{|c|}{ 遭遇調査 } & \multicolumn{2}{|c|}{ 追跡調査 } & 定点調査 \\
\hline 調査方法 & \multicolumn{2}{|c|}{\begin{tabular}{|l|} 
設定ルートに沿って移動し、遭遇した対象者を写真撮影、 \\
撮影が困難な場合は平面図上に記録
\end{tabular}} & \multicolumn{2}{|c|}{\begin{tabular}{|l|}
$\mathrm{CH}$ 利用者を追跡し、行動内容・時間・移動ルート・性別 \\
•年齢・持ち物を記録、写真撮影
\end{tabular}} & $\begin{array}{l}\mathrm{CH} \text { 利用者の } 1 \text { 日の動向をパソコン } \\
\text { のスクリーンキャプチャで記録 }\end{array}$ \\
\hline 調査範囲 & \multicolumn{2}{|c|}{\begin{tabular}{|l} 
複合駅舎および接続する公共空間 \\
\end{tabular}} & \multicolumn{2}{|c|}{ CH エリアを基点とする駅舎内全体 } & $\mathrm{CH}$ エリア \\
\hline 調査期間 & $\begin{array}{c}2011 \text { 年 } 2 \text { 月 } 13 \cdot 14 \cdot 18 \cdot 26 \text { 日 } \\
\text { 3月 } 27 \cdot 28 \cdot 30 \text { 日 } \\
4 \text { 月 } 2 \text { 日 }\end{array}$ & $\begin{array}{c}2011 \text { 年 } 8 \text { 月 } 6 \cdot 8 \cdot 10 \cdot 14 \text { 日 } \\
9 \text { 月 } 14 \cdot 17 \cdot 27 \text { 日 } \\
10 \text { 月 } 2 \text { 日 }\end{array}$ & \begin{tabular}{rl|}
2011 年2月 20 日 \\
3月 $4 \cdot 12 \cdot 14$ 日 \\
4 月 $3 \cdot 4 \cdot 8 \cdot 9$ 日
\end{tabular} & $\begin{array}{c}2011 \text { 年 } 8 \text { 月 } 9 \cdot 11 \cdot 1 \\
9 \text { 月 } 15 \cdot 18 . \\
10 \text { 月1 }\end{array}$ & 2011 年 12 月 $13 \cdot 15$ 日 \\
\hline 調査結果 & 1090 アクティビティ & 835 アクティビティ & 216 事例 & 255 事例 & 486 組 661 人 \\
\hline 調査時間 & \multicolumn{4}{|c|}{ 朝 $(7: 30 \sim 9: 30) \cdot$ 昼 $(12: 00 \sim 14: 00) \cdot$ 夕 $(16: 30 \sim 18: 30)$} & $\mathrm{CH}$ 開場時間（8：30２1：00） \\
\hline
\end{tabular}

とを踏まえると、実施設計によって最優秀案の一体性が少なからず 弱められたと判断できる。

\section{4-5. 岩見沢複合駅舎における建築構成の特徵}

(a) (b) を踏まえると、改札利用者は地上階から直接改札へ至る 動線が確保されており、加えて、CH と市役所 SC は回廊と施設配置 により平面的に分離されている、ことが岩見沢複合駅舎の建築構成 の特徴といえる。CH についていえば、駅舎の主な機能である改札 口および市役所 SC から施設配置としても動線空間としても分離さ れた位置づけとなっている。

一般的な設計手法としては、CH はその効用として、比較的大き な開放空間によって他の施設の機能や活動の染み出しや慗がりを生 みだし、動線空間の基点として設定することで多目的に利用される ように計画されることが多い。

しかし、岩見沢複合駅舎は、CH がむしろ他の施設機能（改札口・ 市役所 SC）から切り分けられた存在となっている。CHについてい えば、連続性や一体性ではなく、他施設の機能や活動に帰属しない 独立した空間という性格が強いものとなっていると考えられる。

\section{5. 利用実態調査の概要（表 3)}

第 4 章で導かれた仮説：CH は他施設の機能や活動に帰属しない 独立した空間であるを着眼として、CHにおける利用実態を把握す るため、3つの行動調查を行った。

\section{$5-1$. 遭遇調査}

岩見沢駅全体の利用実態の把握を目的とした。あらかじめ設定し たルートに沿って移動し、遭遇した対象の写真を撮影、撮影が困 難な場合は平面図にプロットともにその様子をスケッチした。ま た、時間帯による偏りをなくすためにその都度スタート地点の変更 を行った。記録するアクティビティ（以下、ACT）は進行方向 $10 \mathrm{~m}$ 以内とし、ルート上を立ち止まることなく一定の速度で移動した。 調查日時は、2011 年の冬期 ・夏期の各期平日 4 日間 ・休日 4 日間、 の計 8 日間、朝 $(7: 30 \sim 9: 30) \cdot$ 昼 $(12: 00 \sim 14: 00) \cdot$ 夕 $(16: 30$ 〜 18:30) の各 2 時間ずつ実施した。その結果、冬期は 1090、夏季 は835の ACT が観察された。

\section{5-2. 追跡調查}

$\mathrm{CH}$ 利用者の一連の行動の実態把握を目的とした。調查の基点エ リアを $\mathrm{CH}$ とし、観察対象者の一連の行動を可能な限り写真撮影し、 行動内容・移動経路・滞在時間・持ち物などを平面図上に記録した。 途中で観察対象者を見失った場合は再び $\mathrm{CH}$ 一戻り再開した。調 查日時は、2011 年の冬期・夏期の各期平日 4 日間・休日 4 日間の 計 8 日間、朝 $(7: 30 \sim 9: 30) \cdot$ 昼 $(12: 00 \sim 14: 00) \cdot$ 夕 $(16: 30 \sim$ 18:30）の各 2 時間ずつ行った。その結果、冬期は 216、夏季は 255
表 4 遭遇調查におけるアクティビティの分類

\begin{tabular}{|c|c|c|}
\hline 分類 & アクティビティ内容 & 具体例 \\
\hline 移 & あろ协点からある地占への通 & 通行する、E \\
\hline 辞 & 行为 & 佇む、荷物の整理、喫煙する \\
\hline 令暇 & 余暇注 & 食事を摂る、読書する、寝る \\
\hline 交流 & 他者と場所を共有して行われるコ & 会話する、立ち話、たむるする \\
\hline 眺望 & 地域の固有資源 (鉄道・風景など) $)$ 認識する行動 & 鉄道を見る、外を見る、街を眺める \\
\hline 宣住 & 不特定多数の人を対象に展開 & イベント、募金活動、ティツシュ配り \\
\hline 鑑賞 & 駅舎デザインや施設を目的とする鑑賞行動 & 駅を撮影、駅を見学、レンガを探す \\
\hline
\end{tabular}

の事例が観察された。

\section{5-3. 定点調査}

CH における利用実態の 1 日の変化の把握を目的とした。調査エ リアはCHとし、駅舎職員を除く利用者の移動経路・滞在時間・滞 在者数・滞在グループ数をパソコン上にキャプチャデータとして記 録した。また、利用者属性を把握するために可能な限り CH の利用 状況を写真撮影した。調查日時は、2011 年の 12 月の平日 2 日間、 調查時間は CH の開場時間（8 時 30 分〜 21 時 00 分）とした。その 結果、486 組 661 人の利用者が観察された。

\section{6. 遭遇調査による利用者行動の分析}

遭遇調查で得られた ACT を表 4 に示す 7 つの行動分類に整理した。 その中で、「眺望」「宣伝」「鑑賞」は一定の志向が明らかであり場 所によって大きく行動が変わることはないものである。一方、「移 動」「休䕀」「余暇」「交流」は、利用者ごとに行動の状態は様々で あり場所の選択も多様である。特に「余餟」は、利用者の目的や志 向が場所の使いこなしへ顕著に現れる ACT である。これらの状態や 場所のバリエーションは、図 1 に示した各エリアの個別の特性を表 すと考えられる。そこで本論文では、「移動」「休櫋」「余暇」「交流」 に注目し、複合駅舎内を階層・管理区域・施設名から 5 つのエリア (1) 3F 駅施設 (2)センターホール (3) 2F 市施設 (4) $1 \mathrm{~F}$ 市施設 (5) $1 \mathrm{~F}$ 駅施設) に分割し、各エリアの特徴を比較分析する。

\section{6-1. $3 \mathrm{~F}$ 駅施設の特徵}

図 9 を見ると、「移動」が $9.4 \%$ (冬期)、 $11.6 \%$ (夏期）と $1 \mathrm{~F}$ 駅施設に次いで 2 番目に多く観察され、動線空間として利用されて いる。また、学生や社会人がベンチに座る「休想」も $15.9 \%$ (冬期)、 $13.4 \%$ (夏期）と全エリアの中で最も多く観察されており、滞留空 間として利用されている。エリア内には改札口および待合コーナー が設置されていることから、電車の発着に伴う「移動」や電車の待 ち時間の「休咊」が、動線空間・滞留空間としての利用に関係して いると考えられる。加えて、主に学生同士がベンチに座ったり通路 の椢に寄りかかって会話する「交流」もCHに次いで 2 番目に多く 観察されている。「余暇」は $1 \mathrm{~F}$ 駅舎に次いで 2 番目に多く、内容と しては『施設利用』と『読み物』で約 $80 \%$ 占める。『施設利用』 


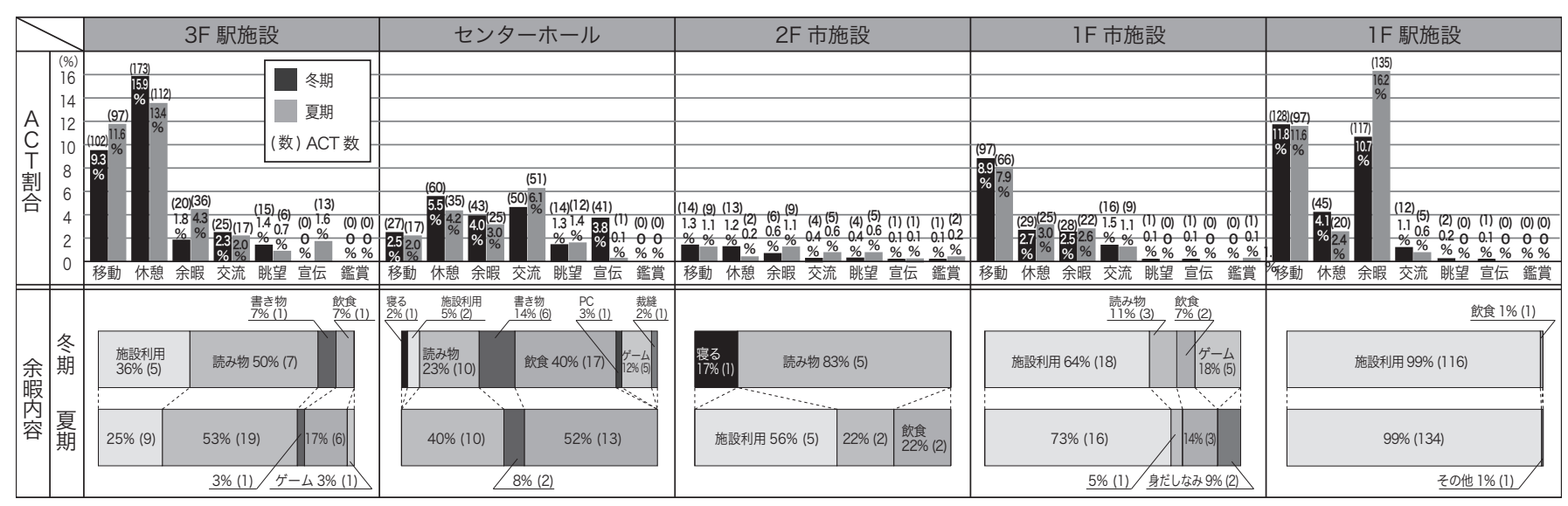

図 9 各エリアにおけるアクティビティの割合と「余暇」内容
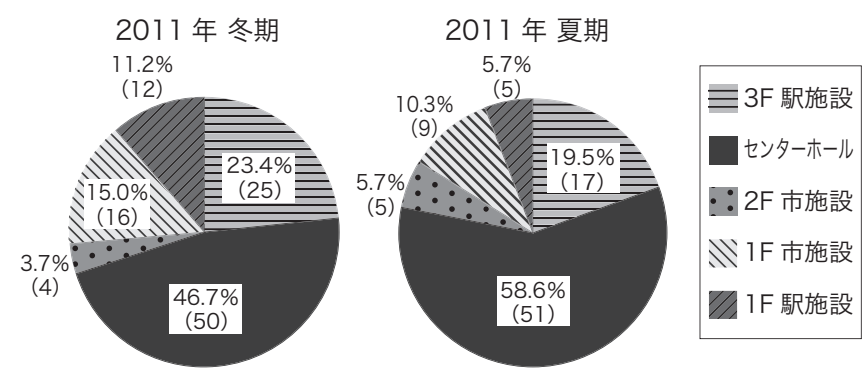

図 10 「交流」が観察されたエリアの割合

は $35.7 \%$ (冬期)、25.0\%（夏期）と多く、施設機能（みどりの空口、 トラベルセンター）との繋がりが強い。また、『読み物』が $50.0 \%$ (冬期)、 $52.8 \%$ (夏期) と多く、他者と活動を共有しない ACT であ ることを踏まえると、少人数の利用に適したエリアとなっている。

\section{6-2. センターホールの特徵}

図 9 を見ると、「移動」が $2.5 \%$ (夏期)、 $2.0 \%$ (冬期）と全エ リアの中で 4 番目に低く、頻繁な移動は観察されなかった。また、 昼には高齢者、夕方には学生によるベンチに座って会話する様子が 多く観察されており、「休秘」は $5.5 \%$ (冬期)、 $4.2 \%$ (夏期) と $3 \mathrm{~F}$ 駅舎に次いで 2 番目に多い。特に「交流」は $4.6 \%$ (冬期)、6.1\% (夏期) と全エリアの中で最も多く観察されている。「余暇」は $3 \mathrm{~F}$ 駅舎に次いで 3 番目に多く観察されており、内容としては、『読み物』 は $23.3 \%$ (冬期)、 $40.0 \%$ (夏期) と多く観察されている。他の工 リアと比べた特徴として昼は全年代、夕は学生がベンチに座って弁 当やパンを食べる『飲食』が $39.5 \%$ (冬期)、 $52.0 \%$ （夏期）と最 も多い。冬期には、ベンチに『寝る』行動や PC 利用、裁縫 (『その他』) など多様な内容が観察され、積雪により外部での活動が制限される 冬期において多様な ACT を受容しているエリアといえる。

\section{6-3. $2 \mathrm{~F}$ 市施設の特徵}

図 9 における全ての ACT の観察数が最も少なく、全エリアの中で 最も利用頻度の低いエリアとなっている。また、エリア内にある市 役所 SC、パスポートセンターなどの市施設の利用率は他のエリア と比較するとかなり低くなっていることから、市施設と駅施設では 利活用に大きな開きがわることがわかる。「余暇」は $0.6 \%$ (冬期)、 $1.1 \%$ (夏期) と最も低い。内容としては『施設利用』の他にも『寝 る』『読み物』『飲食』が設置してあるベンチで観察されており、滞 留空間としての利用は僅かながら観察された。

\section{6-4. 1F 市施設の特徵}

図 9 を見ると、「移動」が $8.9 \%$ (夏期)、 $7.9 \%$ (冬期）と $1 \mathrm{~F}$ 駅 施設に次いで 2 番目に高く、動線空間として利用されている。また、 少数ではあるが荷物整理や会話などの「休䕀」「交流」は、テーブ ルと椅子が設置されてある空きスペースで主に観察されており、動 線空間の中でアルコーブが滞留空間として利用されている。「余暇」 は $2.5 \%$ (夏期)、 $2.6 \%$ (冬期) と少なくなっているが、内容とし ては主に店舗（障がい者ショップ）や自販機を利用する『施設利用』 が $70 \%$ 近くを占めており、施設機能との繋がりが強い。少数なが ら空きスペースで「読み物」「書き物」「飲食」「ゲーム」などが観 察された。

\section{6-5. $1 \mathrm{~F}$ 駅施設の特徵}

図 9 を見ると、「移動」が 11.8 が\%（冬期）、 $11.6 \%$ (夏期）と 5 つのエリアの中で最も高く、「休嚊」「交流」は $2 \mathrm{~F}$ 市施設に次い で 4 番目に低くなっており、主として動線空間として利用されてい る。当該エリアはエントランスから改札口までの最短動線に位置し ていることが、動線空間としての利用に関係していると考えられ る。「余暇」は $10.7 \%$ (冬期)、 $16.2 \%$ (夏期）と 5 つのエリアの 中で最も高いが、その内容は店舗などで買い物をする『施設利用』 が 90\%以上を占めており、施設機能との繋がりが強い一方で、滞 留空間としての利用は低い。

\section{6-6. 各エリアとの比較からみたセンターホール利用の特徵}

各エリアと比較すると、CH は「休嚊」「交流」の割合が高く、滞 留空間として利用されている。さらに 2 人以上のグループによる「交 流」に着目すると（図 10）、CH では冬期・夏期を通して駅舎内の「交 流」のや約半数が行われていることから、全エリアの中で最も複数 人での利用傾向が高い滞留空間となっている。また、「余暇」では、 CH 以外では『施設利用』が一定の割合を占めている一方で、 $\mathrm{CH}$ は 『施設利用』が少なく施設機能の影響が少ない。CH は多様な ACT を 許容し、特に『飲食』といった私的な志向による行動が多く見られ ることから、使いこなしの自由度が高いエリアであるといえる。

\section{7. 追跡調査による利用者行動の分析}

追跡調查で得られた事例を、CH における行動と $\mathrm{CH}$ 以降の行動に 区別して分類を行った（図 11）。CHにおける行動は、滞留型（ベン チなどに滞留する行動)、施設利用型 (CH に付属する施設・設備の 利用行動) 、通過型 ( CH を通過する行動) とし、CH 以降の行動は、 


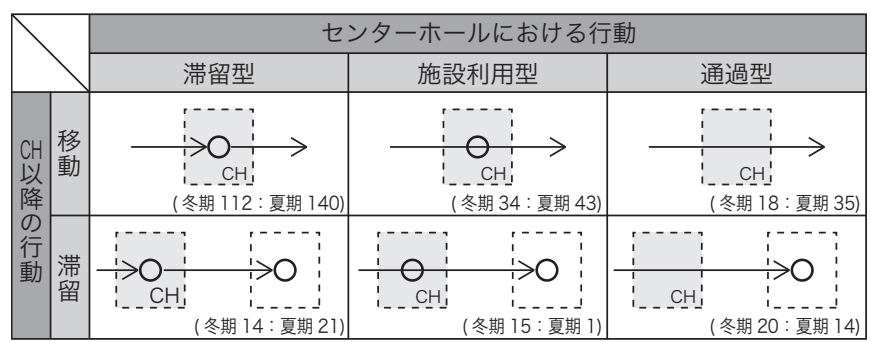

※1：( ) 内は (冬期 : 夏期) における事例数を示す。

※2: 図は以下を示す。滞留行動 : : : 滞留場所 $\rightarrow$ 移動

図 11 センターホールにおける一連行動の分類

移動（立ち止まらずにエントランス、改札口に向う行動）と滞留（バ ンチなどに滞留する行動）とした。

一般に、CH に類する空間は、滞留行動や CH に接続する施設・設 備の利用との繋がりを想定して設計・運営される。よって、CHに おける通過型は、滞留型・施設利用型に比べて期待されない行動で あるとみなすことができる。通過型のうち、CH 以降の行動で移動 のみが観察された事例は、CH を動線空間として利用した一連行動 であるといえる。一方、CH 以降の行動で滞留が観察された事例は、 滞留の場を $\mathrm{CH}$ 以外で求めていることを意味する。よってここでは、 通過型かつ CH 以降に滞留する一連行動を、滞留の場の探索行動之 捉え注目し分析を行う。

\section{7-1. 滞留の場の探索行動パタンの特徵}

滞留の場の探索行動を、CH 通過後に滞留した場所へ向う移動ルー トに着目し、その一連行動を分類すると 4 パタンに分類できた（図 12)。それぞれのパタンについて、移動ルートの傾向から特徵を分 析し、探索行動からみた $\mathrm{CH}$ の特徵を考察する。

(1) スルー

$3 \mathrm{~F}$ から $\mathrm{CH}$ を通過後、2F 市施設のベンチに座る探索行動が多い。 $\mathrm{CH}$ を滞留の場として選択せず他の場所で滞留しており、結果的に CHよりも他の空間を滞留の場として優先した行動といえる。

(2) リターン

$3 \mathrm{~F}$ から $\mathrm{CH}$ を見下ろして、もと来たルートを引き返し、待合スペー スに座る探索行動が多い。CH を見て引き返していることから、CH と他の場所を比較し、他の空間を滞留の場として選択した行動とい える。

\section{(3) スルー×リターン}

$\mathrm{CH}$ を通過後、 $2 \mathrm{~F}$ 市施設のベンチを見て $\mathrm{CH}$ のベンチに座る探索行 動が多い。CH 内のベンチが空いていたが、他の場所へ移動した結果、 そこでは座れなかったので CH に戻ってきて着座した一連の行動で ある。CHよりも他の空間を滞留の場として優先した行動といえる。

\section{(4) リターン×リターン}

1 事例のみとなっているが、 $3 \mathrm{~F}$ から $\mathrm{CH}$ を見下ろした後引き返し て $1 \mathrm{~F}$ に行き、 $1 \mathrm{~F}$ 市施設の空きスペースに行くが、再び引き返して $\mathrm{CH}$ に座る探索行動である。CH よりも他の空間を滞留の場として優 先した行動といえる。

\section{7-2. 探索行動からみたセンターホール利用の特徵}

探索行動パタンから、CHよりも他の場所を滞留空間として優先・ 選択する一連行動が明らかとなった。特に、スルーメリターン、 リターンメリターンのように、CH 内で座ることのできる場所があ るにもかかわらず、他の場所を探す行動がみられていることから、
CH は滞留の場として避けられる何らかの性質があると考えられる。

\section{8. 定点調査による利用者行動の分析}

追跡調査から導かれた仮説：CH は滞留の場として避けられる性

質があるを検証するために、CH の定点調査をもとに CH の利用を避 ける行動についての詳細な分析を行う。

8-1. センターホールにおける1 日の利用傾向（図 13, 図 14）

CH のベンチに滞留する利用者（ベンチ滞留者）は、午前から昼 の時間帯では 1 人での利用が多い。一方、夕方からは複数人グルー プの利用が増加し、いくつかのグループが同時に滞留する場合も多 くみられており、ベンチ利用者の総人数も増加する傾向にある。ま た、夕方のベンチ利用は主に学生であり、複数人でしゃべって騒ぐ 様子も観察された。

CH のベンチ以外に滞留する利用者（周辺滞留者）は、午前から 昼の時間帯は 1 人が短時間滞留する傾向があった、夕方には複数人 グループが同時に滞留する傾向が一定時間みられ、複数人グループ は主に学生であることが観察された。また、3F の CH を見下ろせる 通路が滞留の場所として主に利用されていた。

\section{8-2. 周辺滞留からみたセンターホールにおける飽和状態（図 15，図 16）}

複数のグループが $\mathrm{CH}$ の周辺で連続的に滞留する状態が調查した 両日ともにみられた。ここでは、CH 周辺に滞留している複数グルー プが CH のベンチに座る場所が無いと判断したと見なし、この時の CH の状態を飽和状態と寸る。飽和状態前後における周辺滞留者の 行動・ルート・滞留場所を捉え、周辺滞留の分析を行う。

2011 年 12 月 13 日（火）：5〜 11 人の学生グループが CH のベンチ に滞留している間に、4グループ計 7 人が連続的に滞留する様子が 観察された。なお、ベンチは常に空いている状態であった。周辺 滞留者の滞留の場所をみると、3F 通路に滞留するグループが 3 つ、 CH 階では空際に立って滞留していたグループが 1 つ観察された。 CH 階の空際に滞留していた周辺滞留者は、駅前広場のクリスマス ッリーの写真を撮る行動であった。3F 通路に滞留していたグルー プは、立ち話であった。

2011 年 12 月 15 日（木）: ベンチ滞留者のグループ数が 12 月 13 日 に比べて多く観察されており、大半が学生となっていた。なお、飽 和状態ではベンチが埋まっている状態と空いている状態の両方で周 辺滞留者が観察された。周辺滞留者の滞留場所をみると、3F 通路 に滞留するグループが 4 事例、CH 階では $2 \mathrm{~F}$ エレベーター前に腰を 下ろして滞留していたグループ、2F トイレ前に立って滞留するグ ループ、i-box 前で立って滞留するグループがそれぞれ 1 事例ずつ 観察された。i-box 前のグループは設置されているチラシを見る行 動であったが、その他のグループは立ち話であった。

\section{8-3. 飽和状態からみたセンターホールの非共有利用}

定点調査により、飽和状態としては、ベンチが埋まっている状態 と空いている状態の両方が観察された。周辺滞留者の傾向として、 必然的に周辺滞留が発生するベンチが埋まっている状態よりも、心゙ ンチが空いている状態の事例の方が多く観察され、それが連続的に 発生している点は注目すべきである。

周辺滞留者数最大時までのプロセスを追うと、12月13日（図 17)では、19:16:04にベンチが空いている状態で $3 F$ 通路に滞留して、 その後増加し、19:23:35 には、ベンチ滞留者と周辺滞留者の比が 9 


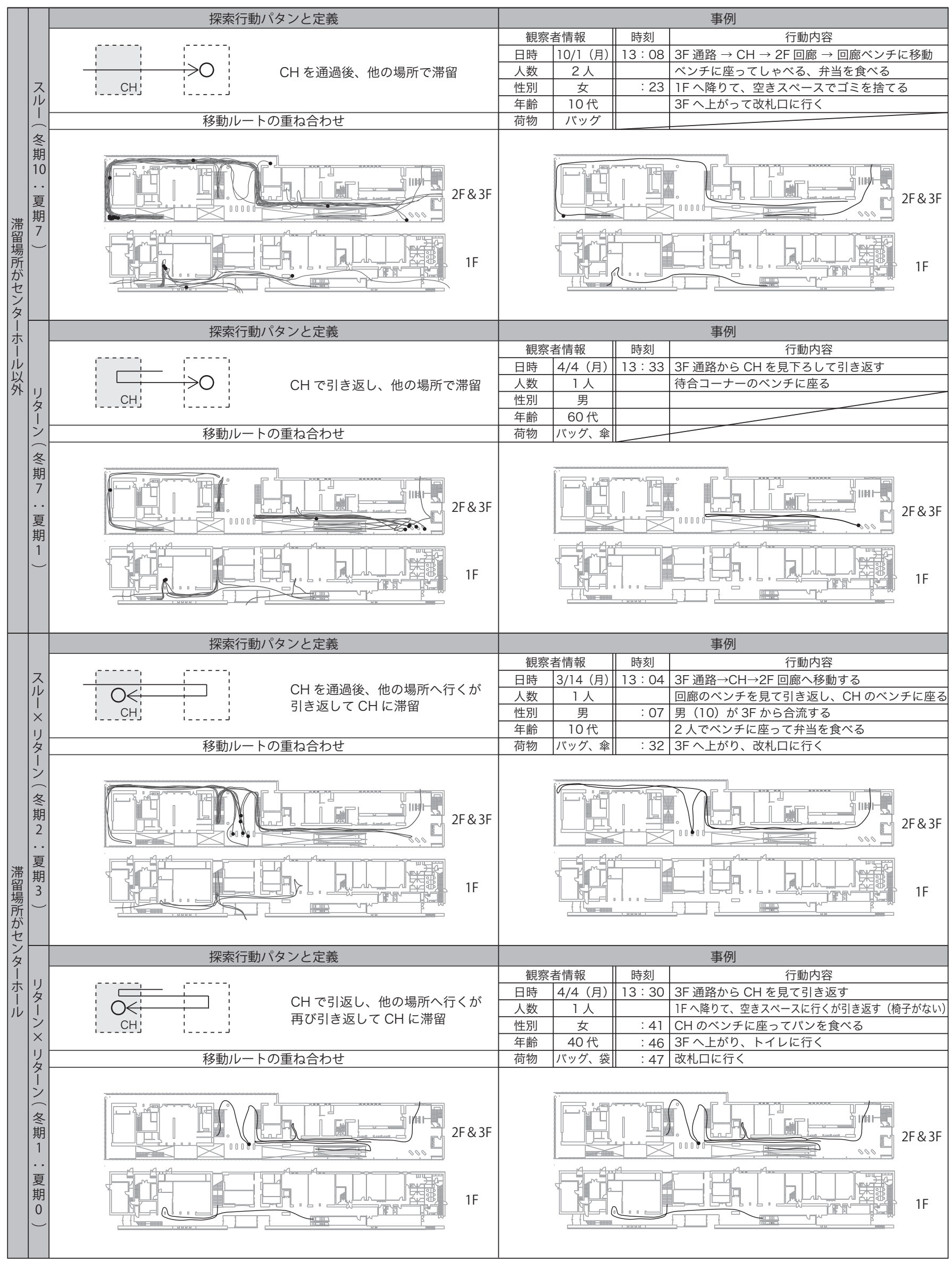

※1：図面中の・は観察者が一連行動の中で滞留した場所を示し、（上：下）内は（冬期：夏期）における事例数を示す。

図 12 探索行動パタンと移動ルート 

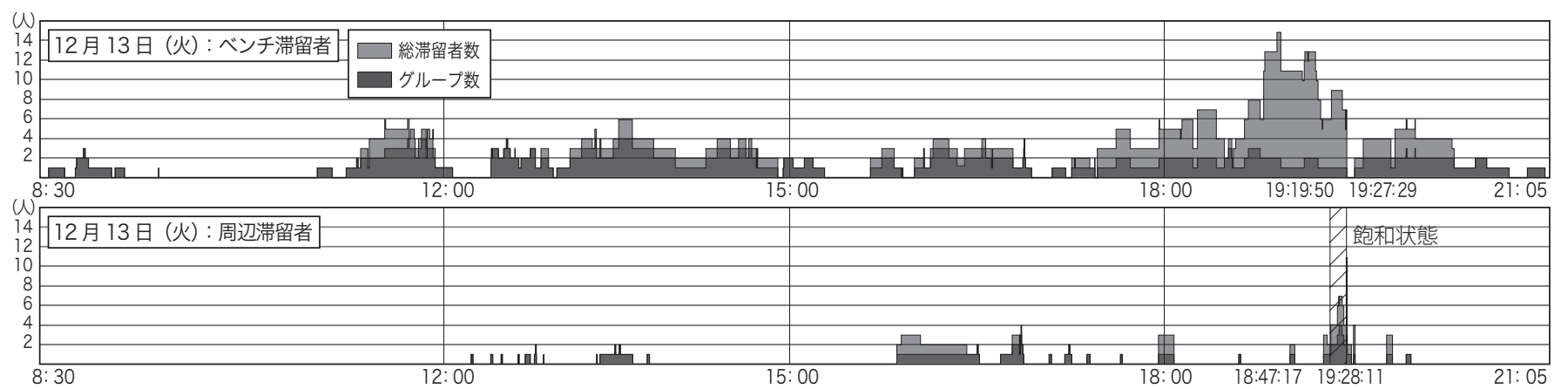

図 13 ベンチ滞留者と周辺滞留者の推移（2011 年 12 月 13 日）
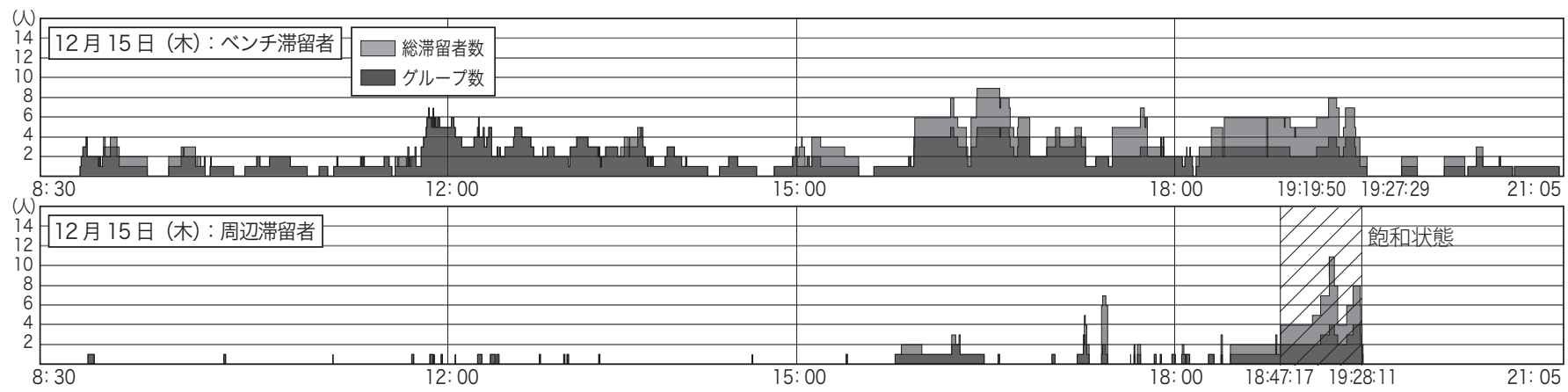

図 14 ベンチ滞留者と周辺滞留者の推移（2011 年 12 月 15 日）
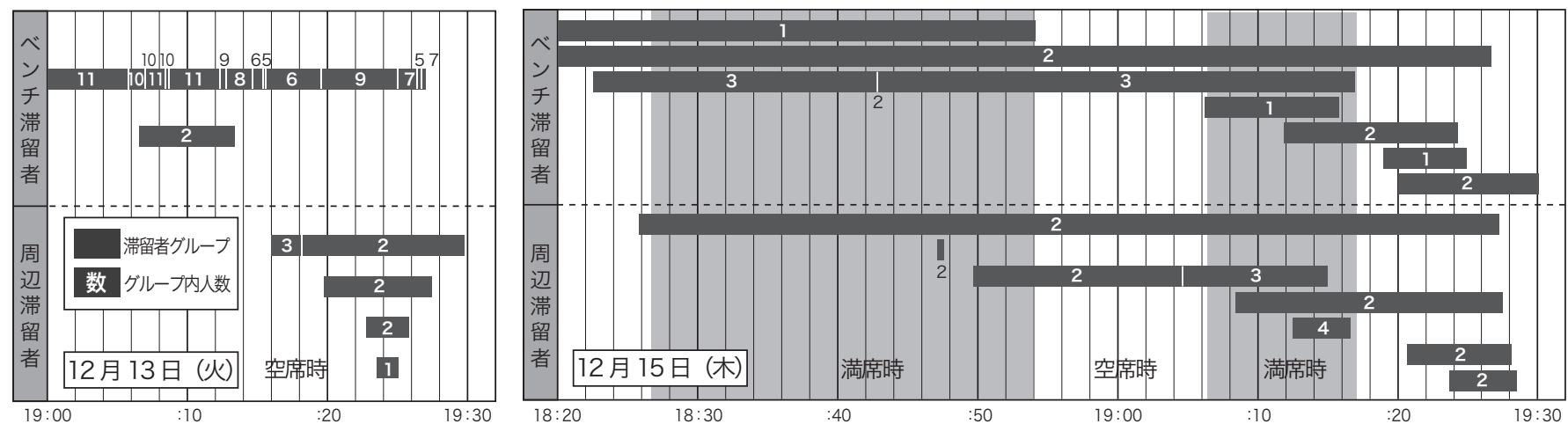

図 16 飽和状態前後におけるベンチ滞留者と周辺滞留者の推移

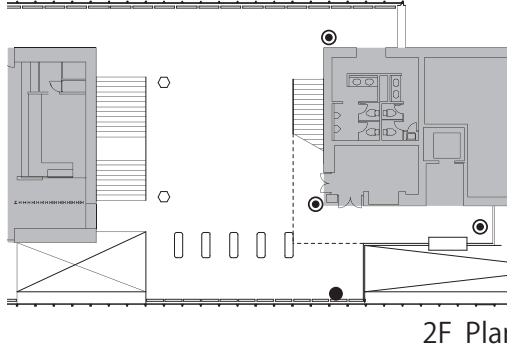

図 15 周辺滞留者の滞留の場所

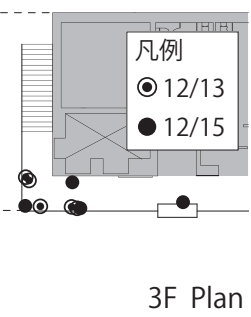

人 $(1$ グループ) : 7 人 $(4$ グループ) となった。

12 月 15 日（図 18）では、18:26:21にベンチが埋まっている状 態で $3 \mathrm{~F}$ 通路に滞留して、その後ベンチの空いている状態でも増加 し、19:25:08 には、ベンチ滞留者と周辺滞留者の比が 4 人（2 グルー プ) : 8 人 $(4$ グループ $)$ となった。 12 月 15 日には、ベンチが埋まっ ている状態からベンチ滞留者が移動して空いている状態に変化した 場合でも、周辺滞留者はそのままその場に滞留し続けた場面がみら れた。
周辺滞留者数最大時には、両日とも周辺滞留者数がベンチ滞留者 数とほぼ同数かそれ以上となっており、周辺滞留者が増えても $\mathrm{CH}$ の空いているベンチには座らない傾向を捉えることができた。

滞留場所ごとにみると、 $3 \mathrm{~F}$ 通路が 7 グループ、 $2 \mathrm{~F}$ ではエレベーター 前・トイレ前・空際・i-box 前でそれぞれ 1 グループとなった。空 際と i-box 前のグループは設備の利用や眺望といった行動であるの に対して、3F 通路を中心とするその他のグループは立ち話などの 場所を限定しない行動であった。場所を限定しない周辺滞留は、3F 通路・ $2 \mathrm{~F}$ エレベーター前・ $\mathrm{F}$ トイレ前と、それぞれ $\mathrm{CH}$ から少し離 れた場所で見られ、CH はベンチ以外にも十分なスペースがあるに もかかわらず、ベンチ以外での滞留が観察されず、特定のベンチ滞 留者のみが CH を利用している状態であることが明らかとなった。

以上より、CH は滞留の場として年齢層や属性を問わず様々な利 用者に活用されているというわけではなく、両日を通して観察され た学生のグループが CH に 50 分以上滞留してしやべる・騒ぐといっ た使われ方が示寸ように、特定の利用者による占有的な場となって いると指摘できる。 


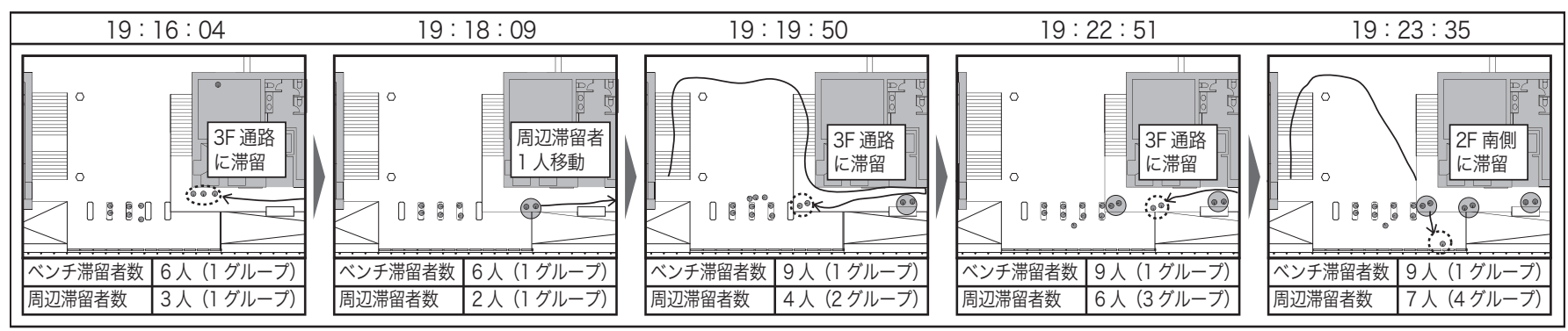

図 17 最大周辺滞留者数までのプロセス（2011 年 12 月 13 日）

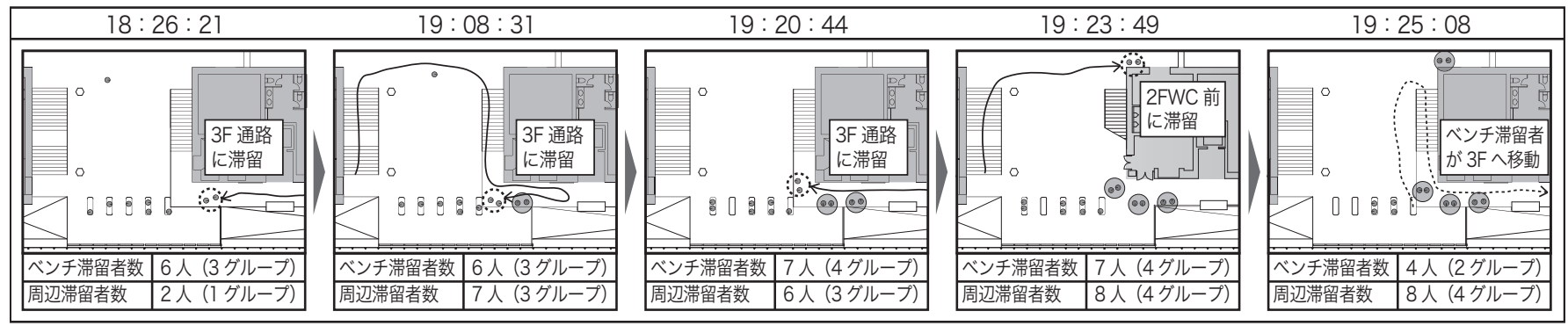

図 18 最大周辺滞留者数までのプロセス（2011 年 12 月 15 日）

9. まとめ

岩見沢複合駅舎の空間特性は以下のようにまとめられる。

- $\mathrm{CH}$ が改札口・市役所 SC の利用者動線から切り離されており、各 施設が独立した空間となる建築構成である

- $\mathrm{CH}$ の独立性は利用者による自由な滞在や使いこなしを許容し、 鉄道や市サービスの利用以外の様々な活動が行える場所となっ ている

- CH での滞在の仕方の自由度がある一方で、用途が明示されない . 他の施設の影響受けない空間が独立することで、特定の利用者に よる占有的な状況を生み、必ずしも広い利用者層に開かれた場所 とはなっていない

岩見沢複合駅舎の CHにおける学生を中心に溜まる・騒ぐといっ た利用や「飲食」「寝る」といった利用は、通勤・通学のための利 用者が多い本来の駅舎用途に適った使われ方であるといえる。利用 者が制限されることなく自由に滞在できるような性質は、CH が改 札口と市役所 SC から分離されることによって独立性が高められて いるからである。この建築構成が利用者の能動的な使いこなしを誘 発しているともいえ、駅舎内での賑わいの創出へと貢献していると 評価できる。

その一方で、本研究により、特定の利用者の私的な志向性により $\mathrm{CH}$ が占有される状況、他の利用者が $\mathrm{CH}$ の利用を避けるといった非 共有的な活動状況が明らかになった。他の施設からの独立性が高く かつ特定の用途が明示されていない $\mathrm{CH}$ は、いったんある利用者が 滞在すると、その利用状況の性質を帯びることになる。本来は年齢 層や属性を問わず様々な利用者が各々に過ごせることが期待される パブリックスペースにおいて、このような排他性を生み出している のは、CH と他の施設との物理的・心理的な距離によって $\mathrm{CH}$ が死角 的な場所となっているからだとも指摘できる。

また、CH のベンチの設置数・設置場所などの設備も重要である。 定点調査において示したように、夕方を中心にベンチが埋まってい る状態が発生しているが、竣工当初から変わらない設置数では利用
人数に対応できていないことがわかる。他者を避ける行動には、べ ンチのレイアウト（ソシオペタルソソンフーガル）のあり方も強 く影響していると考えられる。家具等のあり方は空間利用に大きく 影響することはいうまでもなく、施設の管理・運営において今後の 改善が期待される。

以上のように、設計コンペの意図や選考における評価と照らし合 わせると、CH は複合施設の一体化一寄与する空間的な要としての 役割を担い切れているとは必ずしもいえない。使用方法が明記され ずに設計条件として提示された $\mathrm{CH}$ は、その場の創出や活用の方法 のアイデアを設計コンペに期待した。それならば、最終案から実施 設計への議論の過程において、制限や管理を緩め利用者に使いこな しを委䄈る開かれた場所として CH がどのような役割を担うのかの 視点から、より綿密な設計手法の精查が必要だったといえよう。

本研究では、岩見沢複合駅舎の設計過程において、発注者側が CH について何を期待し、設計コンペと実施設計に対してどのよう な体制で取り組んだのかについての詳細な分析は行えていない。地 域コミュニティ施設の一つとしての複合駅舎の可能性を検討する上 では、それらの検討は今後の重要な課題である。

\section{参考文献}

1）竹澤晋一・上浦正樹・臼井幸彦：鉄道駅における「駅らしさ」に関する基 礎的研究, 日本建築学会計画系論文集, No553, pp. 177-184, 2002.3

2）諏訪正浩・佐野友紀・高橋鷹志・佐藤将之：地域性を重視した鉄道駅空間 における環境行動研究, 日本建築学会大会学術講演梗概集 (E-1), pp. 391392, 2007. 8

3）（株）北海道ジェイ・アール・エージェンシー：まち再生への挑戦 岩見 沢駅舎建築デザインコンペ作品集，北海道旅客鉄道 (株 ), 2006.4

4）岩見沢レンガプロジェクト事務局：駅・復権！-JR 岩見沢複合駅舎誕生と まち再生への軌跡-，岩見沢複合駅舎完成記念誌制作委員会，2010.3

5）株式会社ワークヴィジョンズ：岩見沢複合駅舎（岩見沢駅 + 有明交流プラ ザ+有明連絡歩道)，2009

6）岩見沢レンガプロジェクト事務局・他：ひとつのレンガから〜岩見沢複合 駅舎開業〜，北海道旅客鉄道（株），2009.8

7）倉谷正・鈴木栄基：JR 岩見沢駅新駅舎 駅を核とするまちづくり デザイ ンコンペから市民協働プロジェクトへ， センターリポート，北海道建築指 導センター, Vol37, No4, 2008.1 